\title{
KEBAHAGIAAN SUBJEKTIF PADA WANITA PEKERJA PUTTING OUT SYSTEM DI KABUPATEN SIDOARJO
}

\author{
Eky Oktavia Anggraini ${ }^{1}$, Lely Ika Mariyati \\ Fakultas Psikologi, Universias Muhammadiyah Sidoarjo \\ ekyoctavia@gmail.com
}

\begin{abstract}
This research was motivated by UMKM in Sidoarjo Regency, totaling 2635 businesses involving female workers as employees, one of whom was a homeworker. This study aims to describe the description of women's subjective happiness who work with the putting out system. The method used in this study is qualitative with a case study approach. The subject of this study amounted to 3 women workers with putting out system. Determination of research subjects using purposive sampling technique. Data collection methods using semi-structured interview techniques. The results of the study describe each subject experiencing subjective happiness such as being satisfied with themselves, satisfied with life with family, good relations with peers, optimistic about the future, satisfied with health conditions and enjoying leisure time with family. Each subject has a picture of positive affect as well as feeling happy with the work that is currently occupied and does not cause signs of depression, sadness, despair so that there is no negative affect resulting from working with the putting out system.
\end{abstract}

Keywords: Subjective Happiness, Female Putting Out System Workers, UMKM

\begin{abstract}
ABSTRAK
Penelitian ini dilatarbelakangi oleh UMKM yang berada di Kabupaten Sidoarjo yang berjumlah 2635 usaha melibatkan pekerja wanita sebagai karyawan salah satunya pekerja rumahan. Penelitian ini bertujuan untuk mendeskripsikan gambaran kebahagiaan subjektif wanita yang bekerja dengan putting out-system. Metode yang digunakan penelitian ini adalah kualitatif dengan pendekatan study kasus. Subjek penelitian ini berjumlah 3 orang wanita pekerja dengan putting out system. Penentuan subjek penelitian menggunakan teknik purposive sampling. Metode pengumpulan data menggunakan teknik wawancara semi terstuktur. Hasil penelitian menggambarkan masing-masing subjek mengalami kebahagiaan subjektif seperti puas dengan diri sendiri, puas dengan kehidupan bersama keluarga, berhubungan baik dengan teman sebaya, optimis dengan masa depan, puas terhadap keadaan kesehatan dan menikmati waktu luang bersama keluarga. Masing-masing subjek memiliki gambaran afek positif seperti halnya merasa gembira dengan pekerjaan yang saat ini ditekuni dan tidak memunculkan tanda depresi, kesedihan, putus asa sehingga tidak ada afek negatif yang ditimbulkan dari bekerja dengan putting out system.
\end{abstract}

Kata Kunci: Kebahagiaan Subjektif, Pekerja Wanita Putting Out System, UMKM 


\section{PENDAHULUAN}

Istilah dewasa bermula dari bahasa latin yang merupakan kata kerja, seperti nama adolescene-adolescere yang bermakna adulth bersumber dari wujud lampau pada kata kerja adultus yang memiliki arti tumbuh sebagai kekutan serta bentuk yang sempurna atau telah menjelma dewasa. (Hurlock, 1980). Pada masa dewasa terbagi menjadi 3 periode yaitu masa dewasa dini, masa dewasa madya, dan masa dewasa lanjut (usia lanjut). Masa dewasa Madya dimulai pada umur 40 tahun sampai 60 tahun, yang ditandai dengan menurunnya kemampuan fisik juga psikologis yang begitu nampak pada setiap individu (Hurlock, 1980). Tugas perkembangan pada usia dewasa madya berkaitan dengan perubahan fisik, perubahan minat, penyesuaian kejujuran serta berkaitan dengan kehidupan berkeluarga. Salah satu tugas penting pada masa ini berhubungan dengan seseorang sebagai pasangan baik menjadi suami maupun menjadi istri, menjadi orang tua dengan jumlah anak yang dimiliki. Usia dewasa madya sering membawa perubahan minat dalam kehidupan sosial. Sebagai pasangan harus bertanggung jawab pada kehidupan keluarganya, seperti bertanggung jawab akan status ekonomi keluarga.

Pada wanita dewasa madya juga mengalami perubahan simbol status, yaitu: 1) Mengeluh akan kehidupan ekonomi rumah tangganya yang tidak mencukupi untuk memperoleh status tersebut; 2)Bersifat boros juga hedonis sehingga menjerumuskan keluarganya pada hutang dan yang ketiga berbuat sesuatu dengan bekerja agar mempunyai cukup uang demi mencukupi kebutuhan. (Hurlock, 1980). Pada tahap ini juga merupakan masa krisis, karena individu terbebani oleh berbagai permasalahan rumah tangganya, terlebih masalah finansial, mulai dari penyewaan atau membayar listrik, PDAM, biaya perawatan rumah, perawatan anak, sekolah anak, dll.Pada kondisi tersebut individu yang telah berkeluarga, khususnya pihak wanita untuk membantu perekonomian keluarga dengan bekerja. Wanita dianggap mampu memasuki bidang dan pekerjaan yang biasanya 
dilakukan oleh pria tetapi tidak menghilangkan kodratnya sebagai wanita seperti hamil, melahirkan, menyusui, merawat dan mengurus rumah tangga serta mendampingi suami (Santrock, 2011).

Meningkatknya peran wanita diluar rumah sebagai wanita yang bekerja kenyataannya mereka juga berperan untuk meningkatkan kedudukan keluarga (family status production). Hal ini sejalan dengan penelitian yang dilakukan oleh (Roboth, 2015) mengemukakan bahwa semakin tinggi konflik keluarga-pekerjaan maka akan mengurangi kinerja karyawan wanita. Akan tetapi sebagian wanita memilih untuk tetap dirumah agar memiliki waktu untuk keluarganya. Para pekerja ini membawa pekerjaan dan alat-alatnya yang seharusnya dikerjakan dipabrik dibawah kerumah.Pada umumnya sistem pekerjaan ini lebih banyak dilakukan oleh pengusaha UMKM, karena lebih efisien dan tidak terikat kontrak dengan produsen. Seperti halnya di kabupaten Sidoarjo yang terkenal dengan kota UKM. Saat ini Kabupaten Sidoarjo memiliki 171.264 Unit Usaha MikroBukan tidak mungkin dengan begitu banyak usaha mikro, banyak membutuhkan tenaga kerja salah satunya dengan sistem putting out system. Di Kabupaten Sidoarjo memiliki kabupaten industri dengan 2.635 perusahaan besar, menengah dan kecil termasuk home industry yang banyak melibatkan buruh/pekerja perempuan. Sidoarjo juga sebagai Kabupaten UMKM terbesar se Indonesia tahun 2015 (Fauziah, Mashudi, Mariyati, Choiriyah, 2017)

Pekerja rumahan yaitu seseorang yang melakukan pekerjaan didalam rumahnya atau tempat lain sesuai dengan pilihannya selain dari tempat yang memberi pekerjaa dengan proses upah yang didapatkan dari hasil produk atau jasa yang dinginkan oleh pemberi kerja tanpa memandang siapa yang memasok perlatan, bahan atau yang lain. Hubungan kerja seperti itu sangat merugikan pekerja. Pada umumnya, mereka dibayar setiap hari tanpa manfaat dan tidak ada kepastian keberlanjutan kerja. Sistem kerja yang seperti itu merupakan sistem kerja dengan putting out system (POS) yang pelaksanaan produksi dilakukan diluar tempat, tidak di dalam industri itu melainkan dibawah kerumah(Fajerman, 2013). Upah mereka lebih rendah daripada pekerja laki-laki, mereka dianggap lajang, mereka tidak menerima tunjangan keluarga, dan jaminan sosial untuk suami dan anak-anak. 
Para wanita ditempatkan dalam pekerjaan yang memerlukan ketekunan, ketelitian, kerapian, dan hanya melakukan satu model pekerjaan setiap hari sepanjang bertahun-tahun. Meskipun mengandung beberapa resiko, tetapi masih ada pekerja wanita yang tetap melakukannya, seperti yang telah penulis ketahui dari hasil wawancara dari beberapa wanita yang bekerja dengan putting out system.

Bagi sebagian orang pekerjaan seperti itu tidak membawa keuntungan yang pasti, manun dari hasil wawancara yang telah penulis lakukan, ada sisi kebahagiaan tersendiri yang dicapai.

"meskipun tidak besar lumayan bisa beli bensin, beli kebutuhan dapur seperti cabe, tomat. Saya Alhamdulillah bisa bareng dengan keluarga. Aku ndak muluk-muluk yang penting kebutuhan dirumah bisa tercukupi dan saya memiliki waktu dirumah. Dari pada dirumah tidak jelas mau ngapain. Kumpul mau ngerasani tetangga ya saya ndak mau seperti itu”

(Wawancara, 15 Oktober 2017)

Hasil wawancara diatas disimpulkan bahwa subjek merasa bahagia bisa berkumpul dengan keluarga meskipun upah yang didapatkan tidak sebesar ketika bekerja di pabrik. Hal ini sejalan dengan teori yang dikemukakan oleh (Arif, 2016)Kebahagiaan merupakan tujuan akhir dari semua aktivitas, semua daya upaya, semua perjuangan dalam hidup ini. Menurut Seligman (dalam Kasturi, 2015)Kebahagiaan yang dicari merupakan tujuan akhir, artinya tidak ada lagi tujuan lain yang hendak diupayakan setelah mencapai kebahagiaan itu. Kebahagiaan merupakan konsep yang merefer pada emosi-emosi positif yang dirasakan oleh seseorang yang menghasilkan aktivitasaktivitas positif sehingga individu mempunyai keterlibatan penuh (flow) pada aktivitas lainnya. Kebahagiaan subjektif adalah seseorang yang memiliki gambaran kehidupan yang positif dan perasaan yang baik. dengan demikian seseorang yang berbahagia merupakan orang yang memiliki kepuasaan terhadap kehidupan dan jarang mengalami kesedihan atau kemarahan (Eid \& Larsen, 2008)

Menurut wawancara dengan subjek diatas, menggambarkan bahwa kepuasan akan hidup dan mensyukuri apa yang telah diberikan merupakan suatu kebahagiaan yang berharga. Individu yang merasa bahagia akan selalu bersyukur dengan apa yang telah diberikan, meskipun hasil dari 
pekerjaan itu tidak banyak. Hal ini sejalan dengan Diener (Shimmack dalam Eid\& Larsen, 2008)komponen kebahagiaan subjektif yaitu: Kepuasan hidup, pengaruh positif, pengaruh negatif. Dan sejalan dengan penelitian Alfarisi (2010 dalam Prasetyo, 2015), individu yang merasa bahagia akan melakukan pekerjaan dengan sepenuh hati dan menomor duakan imbalan materi. Penelitian ini memiliki manfaat yang secara teoritis untuk memberikan sumbangan bagi perkembangan ilmu psikologi khususnya psikologi positif serta secara praktis sebagai tambahan informasi sebagai bahan masukan bagi ilmuwan psikologi yang akan meneliti tentang variabel kebahagiaan subjektif yang terkait dengan wanita pekerja dengan putting out system, pengusaha dan pemerintah.

Wanita adalah individu berjenis kelamin berbeda secara fisiologis yang tumbuh sejak lahir, kemudian diperkuat oleh sistem kebudayaan yang sudah ada, khususnya oleh adat istiadat, metode sosial-ekonomi dan akibat sistem pendidikan (Kartono, 2007).Menurut Mantra(2004 dalam Nilakusmawati, Susilawati, 2012), bekerja yaitu suatu aktivitas kegiatan untuk menciptakan atau membantu mendapatkan barang atau jasa dengan maksud untuk memperoleh penghasilan berbentuk uang dan atau barang, dalam kurun waktu (time reference) yang ditentukan. Kerja rumahan (home work) merupakan jenis kerja informal yang dilakukan dirumah dalam lingkungan rumah tangga (Wijaya, 1995) Dari penjabaran diatas, disimpulkan dari beberapa pengertian diatas, wanita pekerja putting out system adalah wanita yang bekerja di rumah untuk menghasilkan suatu barang atau jasa dengan maksud untuk memperoleh penghasilan berupa uang. Pekerjaan putting out system ini memiliki karakteristik yang membedakan dengan pekerjaan lain. Menurut (Ihromi, 1995) Ada 3 karakteristik pekerja rumahan (Putting Out System), yaitu : 1) Aktivitas pekerjaan dilakukan di rumah pekerja.2) Hubungan antara majikan-buruh diketahui dengan sub-ordinasi ekonomi dan metode (contohnya majikan secara sepihak menggariskan sistem hubungan kerja, kualitas dan kuantitas produk, upah dan waktu pemberian barang. 3) Pekerjaan rumahan tidak memiliki kuasa untuk menentukan pemakaian dan memasarkan produk dipasar. Pada umumnya wanita yang bekerja dengan putting out system telah berusia diatas 40 tahun. Usia madya atau setengah baya 
dilihat ketika memasuki usia antara 40 sampai 60 tahun (Hurlock, 1980). Jadi dapat disimpulkan dari pengertian diatas bahwa wanita dewasa madya adalah perempuan dewasa yang berkisar 40 tahun sampai 60 tahun.

Menurut Larsen dan Diener (dalam Diener, 2009) kebahagiaan subjektif merupakan kondisi yang cenderung stabil sepanjang waktu dan sepanjang rentang kehidupan.Kebahagiaan subjektif adalah seseorang yang memiliki gambaran kehidupan yang positif dan perasaan yang baik. dengan demikian seseorang yang berbahagia merupakan orang yang memiliki kepuasaan terhadap kehidupan dan jarang mengalami kesedihan atau kemarahan (Eid \& Larsen, 2008). Dari beberapa teori yang telah dipaparkan dapat disimpulkan bahwa kebahagiaan subjektif adalah gambaran terhadap emosi positif dari seseorang yang timbul dari kepuasan kejadian/peristiwa kehidupan yang telah dialami saat ini.

Menurut Diener \& Ryan (2009), beberapa faktor yang mempengaruhi kebahagiaan seseorang adalah: kecerdasan emosional, religiusitas, relasi sosial, pekerjaan dan tingkat pendapatan. Dengan demikian, dapat dikatakan bahwa individu akan merasa bahagia jika memiliki kecerdasan emosi yang baik, bersikap religius, memiliki hubungan sosial yang baik, dan memiliki pekerjaan dan penghasilan yang memuaskan. Aspek-aspek kebahagiaan subjektif menurut Carr (2004) yaitu aspek afektif yaitu spek yang memiliki gambaran terhadap pengalaman emosi berupa kesenangan, kegembiraan, dan kebahagiaan. 2) Aspek kognitif Adalah Aspek yang menggambarkan kepuasan dengan macam-macam domain dalam hidup. Dengan demikian aspek kebahagiaan itu menggambarkan pengalaman emosi yang positif selama dalam rentang kehidupan

\section{METODE PENELITIAN}

Penelitian ini memakai pendekatan kualitatif yaitu penelitian yang memakai strategi naturalistik yang digunakan untuk mencari dan menemukan penjelasan dan pemahaman tentang fenomena suatu situasi yang berkonteks khusus (Moleong, 2017). Jenis penelitian ini adalah studi 
kasus yang merupakan sebuah penggalian yang bermula suatu metode yang terkait atau suatu kasus/ berbagai kasus yang dari waktu ke waktu dengan akumulasi data yang komprehensif serta mengkaitkan beragam sumber informasi yang "kaya" suatu konteks (Creswell, 2010). Pada penelitian ini, subjek sebagai sumber data ditetapkan secara purposive sampling. Purposive sampling merupakan suatu teknik pemungutan sampel sumber data dengan pandangan tertentu yang diharapkan akan memudahkan peneliti menjelejahi objek atau situasi social yang diteliti. Peneliti juga sudah menetapkan subjek yang akan dijadikan informan dengan mengunakan ciri-ciri. Adapun subjek tersebut memiliki ciri-ciri yang telah di tetapkan yaitu berusia diatas 40 tahun dan memiliki pekerjaan yang dikerjakan dirumah dengan sistem borongan (putting out system).

Teknik pengambilan data merupakan proses yang paling penting pada sebuah penelitian. Dalam penelitian ini menggunakan wawancara baku terbuka (terstruktur) yaitu dengan menggunakan seperangkat pertanyaan baku. Wawancara terstuktur digunakan untuk memahami gambaran informasi yang terikat pada fokus penelitian. Dan wawancara tak berstruktur digunakan untuk memulai proses wawancara yang berhubungan dengan permasalahan yang akan diteliti. Wawancara dilakukan pada subjek yang telah ditentukan sebagai sumber data utama yaitu TZ, SK, S. Sebagai pendukung data utama penelitian ini membutuhkan data yang lebih mendalam dan utuh, di perlukan data pendukung yaitu significant other dari subjek yang harus memiliki kriteria sebagai dibawah ini : 1) Memiliki ikatan kekerabatan dengan subjek. 2) Mengetahui aktivitas keseharian yang subjek lakukan. Rumusan pertanyaan yang menjadi pedoman wawancara akan difokuskan pada satu pokok yang menjadi fokus penelitian, yaitu tentang gambaran aspek kebahagiaan subjektif. Selain itu untuk mendukung hasil wawancara, peneliti menggunakan catatan lapangan sebagai bukti pendukung.

Menurut Bogdan dan Biklen (1982 dalam Moleong, 2017) catatan ditulis tentang apa saja yang telah didengar, dilihat, dialami dan dipikirkan dalam bentuk pengumpulan data dan gambara pada data dalam konteks penelitian kualitatif. Catatan dapat berupa coretan seperlunya yang berisi 
kata-kata pokok yang utama, frasa, pokok-pokok isi pembicaraan atau pemantauan, bisa gambar, sketsa, sosiogram, diagram, dll. Pada penelitian ini catatan lapangan yang digunakan seputar aktivitas subjek selama proses wawancara. Dan keadaan setting tempat berlangsungnya wawancara.Untuk kualifikasi keabsahan data yang tinggi maka harus melaksanakan uji keabsahan data dengan menggunakan uji kredibilitas. Ada beberapa jenis triangulasi data menurut Denzin (dalam Moleong, 2017) Empat macam teknik triangulasi pada pemaparan diatas, peneliti menggunakan teknik triangulasi sumber (data) untuk menguji kualitas keabsahan data yang berhubungan dengan masalah pada penelitian yang diteliti.

Pada penelitian ini untuk pemeriksaan keabsahan data menggunakan triangulasi sumber data dengan cara: 1) Membuat perbandingan antara hasil wawancara subjek utama dengan hasil wawancara significant others. 2) Membuat perbandingan antara apa yang dibicarakan oleh orang dengan apa yang dibicarakan secara pribadi. 3) Membuat perbandingan situasi penelitian dari perkataan orang-orang dan dari perkatan individu sepanjang waktu. Menurut Miles dan Huberman(1984 dalam Sugiyono, 2014) kegiatan ketika analisis data kualitatif dilaksanakan dengan cara interaktif dan berlangsung secara berkesinambungan sampai tuntas, sehingga data jenuh. Kegiatan pada saat analisis data yaitu: a) Reduksi Data Penelitian ini merupakan proses pengambilan data dilakukan menggunakan teknik wawancara terhadap subjek dan significant others. Pada saat proses wawancara dilakukan memperoleh data yang cukup banyak, maka dari itu peneliti meringkas dan memilah hal-hal yang cocok dengan fokus penelitian dan memberikan simbol atau kode pada setiap hal yang pokok; b) Data Display (Penyajian Data) yaitu penyajian data dilaksanakan pada bentuk tabel dan dijelaskan pada bentuk narasi cocok dengan hal-hal pokok dan penting yang menjadi fokus penelitian, yaitu berdasarkan gambaran aspek-aspek kebahagiaan subjektif; c) Conclusion Drawing / Verfication yaitu kesimpulan pada penelitian ini merupakan jawaban dari fokus penelitian. Membuat kesimpulan dari data temuan yang sesuai dengan teori yang telah dikemukakan dan hasil dari penelitian lain tentang kebahagiaan subjektif. 


\section{HASIL}

Subjek yang terlibat dalam proses penelitian terdiri dari 3 respondon utama. Profil subjek dapat dilihat pada tabel 1 dibawah ini:

Tabel 1. Profil Subjek

\begin{tabular}{|c|c|c|c|c|c|}
\hline Nama & Usia & Alamat & $\begin{array}{c}\text { Pendidikan } \\
\text { Terakhir }\end{array}$ & Pekerjaan & $\begin{array}{c}\text { Pendidikan } \\
\text { Informal }\end{array}$ \\
\hline $\mathbf{T Z}$ & $\begin{array}{l}45 \\
\text { Th }\end{array}$ & Sidoarjo & SMU & $\begin{array}{l}\text { Gunting-Gunting Pita, Menerima } \\
\text { Orderan Kue }\end{array}$ & Kursus Jahit \\
\hline SK & $\begin{array}{l}46 \\
\mathrm{Th}\end{array}$ & Sidoarjo & SMP & Gunting-Gunting Pita, Jahit Majun & Kursus Jahit \\
\hline $\mathbf{S}$ & $\begin{array}{l}46 \\
\mathrm{Th}\end{array}$ & Sidoarjo & SMP & $\begin{array}{l}\text { Jahit Majun, Menerima Orderan } \\
\text { Kue }\end{array}$ & Kursus Jahit \\
\hline
\end{tabular}

Dari tabel diatas, disimpulkan bahwa subjek pertama, TZ berusia 45 tahun menempuh pendidikan terakhir SMU, memiliki keahlihan menjahit, pekerjaannya menggunting pita dan menerima orderan kue. Subjek kedua SK, berusia 46 tahun, menempuh pendidikan terakhir SMP, memiliki keahilihan dalam menjahit, pekerjaannya mengguting pita dan menjahit kain majun. Subjek ketiga, S, berusia 46 tahun, pendidikan terakhir SMP, memiliki keahlihan dalam menjahit dan pekerjaannya menjahit majun dan menerima orderan kue.

Subjek memiliki pekerjaan putting out system. Karakter pekerjaan putting out system yang dilakukan oleh responden dapat dilihat pada tabel 2 dibawah ini:

Tabel 2. Karakterisik Pekerjaan Putting Out System

\begin{tabular}{|c|c|c|c|}
\hline Karakteristik & $\mathbf{T Z}$ & SK & $\mathbf{S}$ \\
\hline $\begin{array}{l}\text { Aktivitas pekerjaan } \\
\text { dilakukan di rumah } \\
\text { pekerja. }\end{array}$ & Dikerjakan dirumah & Dikerjakan dirumah & Dikerjakan dirumah \\
\hline Sistem upah & $\begin{array}{l}\text { Upah dibagikan } \\
\text { ketika pekerjaan } \\
\text { sudah selesai dengan } \\
\text { sistem setor }\end{array}$ & $\begin{array}{l}\text { Upah dibagikan } \\
\text { ketika pekerjaan } \\
\text { sudah selesai dengan } \\
\text { sistem setor }\end{array}$ & $\begin{array}{l}\text { Upah dibagikan } \\
\text { ketika pekerjaan } \\
\text { sudah selesai dengan } \\
\text { sistem setor }\end{array}$ \\
\hline Fasilitas tunjangan & Tidak ada & Tidak ada & Tidak ada \\
\hline
\end{tabular}


Dari tabel diatas, disimpulkan bahwa ketiga subjek memenuhi karakteristik-karakteristik pekerjaan dengan putting out system. Pada subjek 1, TZ, aktivitas pekerjaannya di kerjakan dirumah, sistem upah dilakukan jika pekerjaan selesai dan disetorkan ke majikan, fasilitas dan tunjangan tidak dapatkan. Pada subjek 2, SK, aktivitas pekerjaannya di kerjakan dirumah, sistem upah dilakukan jika pekerjaan selesai dan disetorkan ke majikan, fasilitas dan tunjangan tidak dapatkan. Pada subjek 3, S, aktivitas pekerjaannya di kerjakan dirumah, sistem upah dilakukan jika pekerjaan selesai dan disetorkan ke majikan, fasilitas dan tunjangan tidak dapatkan.

Setelah dilakukan analisis, diperoleh gambaran kebahagiaan subjektif pada responden. Gambaran kebahagiaan subjektif responden dapat dilihat secara detil pada tabel 3 dibawah ini:

Tabel 3. Gambaran Kebahagiaan Subjektif

\begin{tabular}{|c|c|c|c|}
\hline $\begin{array}{c}\text { Aspek } \\
\text { Kebahagiaan } \\
\text { Subjektif }\end{array}$ & Subjek I & Subjek II & Subjek III \\
\hline \multicolumn{4}{|c|}{ 1. Aspek Kognitif } \\
\hline Diri Sendiri & $\begin{array}{l}\text { Merasa puas dengan } \\
\text { mengoptimalkan } \\
\text { keahlihan yang dimiliki, } \\
\text { bersyukur bisa } \\
\text { menjalankan kewajiban } \\
\text { sebagai ibu dan istri yang } \\
\text { baik, dan meskipun } \\
\text { dirumah masih bisa } \\
\text { menghasilkan. }\end{array}$ & $\begin{array}{l}\text { Menyadari bahwa usia } \\
\text { yang tidak lagi muda tidak } \\
\text { bisa bekerja diluar, mampu } \\
\text { mengoptimalkan } \\
\text { keahlihannya dengan baik, } \\
\text { bersyukur bisa sepenuhnya } \\
\text { dalam mengasuh anak. }\end{array}$ & $\begin{array}{l}\text { Menyadari bahwa usia yang } \\
\text { tidak lagi muda tidak bisa } \\
\text { bekerja diluar, mampu } \\
\text { mengoptimalkan } \\
\text { keahlihannya dengan baik, } \\
\text { bersyukur bisa sepenuhnya } \\
\text { dalam mengasuh anak. }\end{array}$ \\
\hline Keluarga & $\begin{array}{l}\text { Memiliki komunikasi } \\
\text { yang baik antara anak dan } \\
\text { suami, bersyukur anak- } \\
\text { anak tumbuh menjadi } \\
\text { anak yang patuh dan } \\
\text { penurut, memiliki } \\
\text { perkawinan yang utuh dan } \\
\text { keluarga yang mendukung } \\
\text { pekerjaan saat ini. }\end{array}$ & $\begin{array}{l}\text { Komunikasi antara suami } \\
\text { dan anak baik, bersyukur } \\
\text { menjadi anak yang patuh } \\
\text { dan disiplin, memiliki } \\
\text { perkawinan yang utuh, } \\
\text { keluarga yang mendukung } \\
\text { pekerjaan saat ini. }\end{array}$ & $\begin{array}{l}\text { Memiliki komunikasi yang } \\
\text { baik antara anak dan suami, } \\
\text { mampu menjaga keutuhan } \\
\text { rumah tangga meskipun } \\
\text { jauh dengan suami, anak } \\
\text { yang patuh dan disiplin, } \\
\text { keluarga yang mendukung } \\
\text { pekerjaan saat ini. }\end{array}$ \\
\hline $\begin{array}{l}\text { Teman } \\
\text { Sebaya }\end{array}$ & $\begin{array}{l}\text { Memiliki hubungan yang } \\
\text { baik dengan tetangga } \\
\text { maupun dengan teman- } \\
\text { teman lama, aktif dalam } \\
\text { kegiatan lingkungan dan } \\
\text { masyarakat, memiliki rasa }\end{array}$ & $\begin{array}{l}\text { Memiliki hubungan yang } \\
\text { baik dengan tetangga } \\
\text { meskipun selektif dalam } \\
\text { berhubungan dengan } \\
\text { tetangga, berusaha aktif } \\
\text { dalam lingkungan }\end{array}$ & $\begin{array}{l}\text { Memiliki hubungan yang } \\
\text { baik dengan tetangga, } \\
\text { merasa senang jika masih } \\
\text { bisa berperan serta dalam } \\
\text { kegiatan masyarakat }\end{array}$ \\
\hline
\end{tabular}




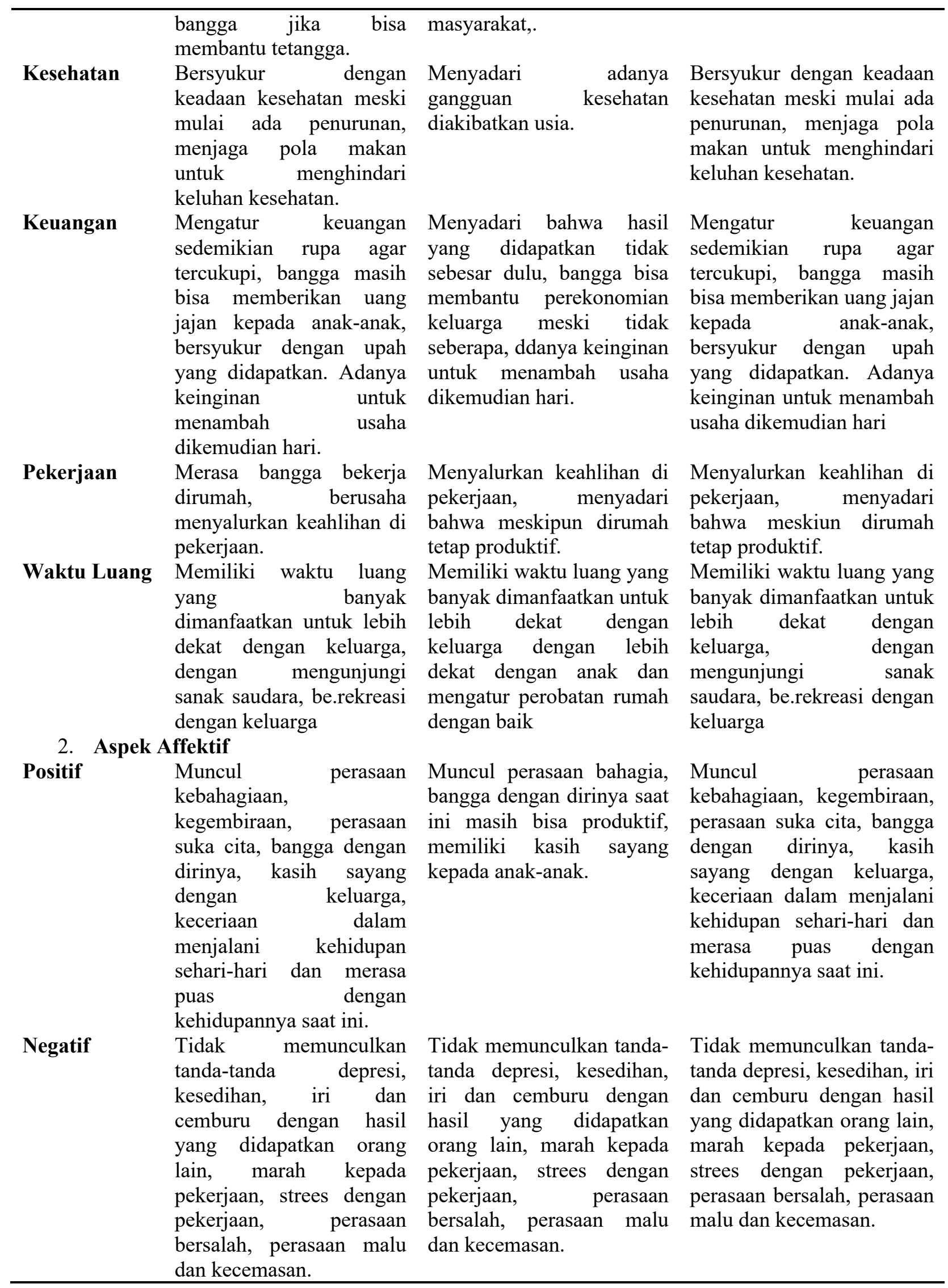




\section{DISKUSI}

Berdasarkan penjelasan diatas dapat disimpulkan bahwa wanita pekerja dengan putting out system memiliki gambaran kebahagiaan subjektif. Hal ini muncul diakibatkan mereka memiliki kepuasan akan kehidupannya saat ini. Kepuasanterhadap kehidupan akan muncul jika individu memiliki upaya untuk mencapai kebahagiaan menjadi fokus perhatian dan tujuan dari manusia sepanjang waktu. Hal ini sesuai apa yang dikemukakan oleh (Schimmel, 2009) menjelaskan bahwa kebahagiaan merupakan penilaian individu terhadap keseluruhan kualitas hidupnya. Kebahagiaan terkadang juga disebut sebagai kebahagiaan subjektif (subjective well being).

Hasil penelitian menunjukkan bahwa ketiga subjek muncul gambaran kebahagiaan dalam kehidupannya saat ini. Memiliki kepuasan terhadap dirinya sendiri, memiliki kepuasan terhadap keluarga, memiliki pola komunikasi yang baik dengan keluarganya maupun dengan tetangga dan teman-temannya dulu.Meskipun saat ini menurunnya keterbatasan fisik, subjek tidak menjadikan keterbatasan fisik itu hambatan untuk terus produktif. Memiliki rasa optimis terhadap kehidupan yang akan datang dan akan ada tambahan usaha yang akan dijalankan seiring dengan kerterbatasan fisik yang dialami.

Menurut (Carr, 2004) aspek kebahagiaan subjektif dibagi menjadi 2 yaitu yang pertama aspek kognitif yang meliputi diri sendiri, keluarga, teman sebaya, kesehatan, keuangan, pekerjaan dan waktu luang. Yang kedua aspek afektif yang meliputi afek positif dan afek negatif.Diparagraf selanjutnya akan dipaparkan lebih lanjut tentang aspek-aspek kebahagiaan subjektif.

Aspek diri sendiri, pada aspek ini ketiga subjek memiliki kepuasan terhadap dirinya saat ini. Hal ini tergambar ketika subjek mensyukuri apa yang sudah didapatkan. Menikmati peran sebagai ibu dan istri yang sepenuhnya. Tetap produktif melakukan aktivitas yang bisa menghasilkan dan tetap bisa memantau perkembangan tumbuh kembang anak-anak setiap saat. Hal ini sesuai dengan kutipan ayat Al Quran yang menjelaskan bahwa bila seseorang itu bersyukur dengan apa yang saat 
ini dialami, maka Allah akan menambah kenikmatan yang diberikan. Kutipan QS. Ibrahim, ayat 7 sebagai berikut:

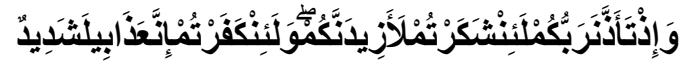

Artinya: Dan (ingatlah juga), tatkala Tuhanmu memaklumkan; "Sesungguhnya jika kamu bersyukur, pasti Kami akan menambah (nikmat) kepadamu, dan jika kamu mengingkari (nikmat$\mathrm{Ku}$ ), maka sesungguhnya azab-Ku sangat pedih". (Q.S. Ibrahim Ayat 7) (Al-Quran dan Terjemahannya Departemen Agama RI, 2014)

Aspek keluarga, pada aspek ini ketiga subjek memiliki kepuasan terhadap peristiwa hidup bersama keluarga. Hal ini terbukti dengan pola komunikasi yang baik dengan anak-anak dan suami subjek. Memiliki bersyukur terhadap anak-anak yang patuh dengan orang tua, yang sesuai dengan apa yang subjek harapkan. Subjek merasa beban pengasuhan sedikit berkurang dengan beranjak dewasanya anak-anak. Ketiga subjek memiliki anak-anak yang sudah beranjak dewasa bahkan ada yang sudah bekerja. Terdapat kepuasan pernikahan yang subjek rasakan, pernikahan yang utuh menjadi salah satu faktor munculnya kebahagiaan. Menurut (Popenoe, 2002 dalam Myers, 2012) seseorang yang memiliki pernikahan yang utuh dan bertahan menjadikan individu tersebut bahagia dan meminimalkan timbulnya stress.

Aspek teman sebaya, pada aspek ini ketiga subjek memiliki penilaian yang baik terhadap orang-orang disekelilingnya. Hal ini terbukti dengan adanya pola komunikasi yang baik antara subjek dengan orang-orang disekitarnya.Meskipun bekerja dirumah, subjek tidak menjadikan hal itu alasan untuk tetap aktif dalam kegaiatan sosial dilingkungan.Memiliki silaturahmi yang baik dan tetap berjalan dengan teman-teman lama. Namun pada subjek II saat ini membatasi aktivitas diluar rumah dikarenakan faktor usia yang tidak memungkin untuk tetap aktif pada semua kegiatan. Subjek II lebih selektif dalam memilih kegiatan apa saja yang akan diikuti.

Aspek kesehatan, ketiga subjek merasa puas dengan keadaan kesehatan yang saat ini dialami. Pada usia subjek saat ini, terjadi perubahan pada keberfungsian fisiologis dan menurunnya kesegaran fisik. Terlebih lagi pada usia ini mendekati dengan masa-masa menopause pada wanita. 
Ketiga subjek mensyukuri apa yang telah diberikan padanya saat ini. Bersyukur ketika anggota keluarga diberikan kesehatan dan bisa beraktivitas sebagaimana mestinya.

Aspek keuangan, ketiga subjek puas dengan apa yang yang dijalankan saat ini. Meskipun penghasilan yang didapatkan tidak sebesar ketika bekerja di pabrik, ketiga subjek menikmati dan menyadari bahwa upah yang didapatkan sedikit. Namun ada sisi kebanggan yang muncul, karena masih bisa produktif meskipun dirumah dan bisa membantu ekonomi keluarga.

Aspek pekerjaan, ketiga subjek puas dengan pekerjaan yang dilakukan saat ini. Tidak terfikir untuk berhenti dengan pekerjaannya saat ini namun ketiga subjek memiliki rencana akan ada usaha tambahan yang akan dijalani. Pada subjek I dan III akan ada usaha tambahan yang sesuai dengan hobbi yang mereka sukai. Pada subjek II akan ada usaha tambahan untuk pemasukan sembari mengerjakan pekerjaan putting out system.

Aspek waktu luang, ketiga subjek merasa puas dengan adanya waktu luang yang bisa dimanfaaatkan untuk lebih intens bersama keluarga. Dengan adanya waktu luang dijadikan wadah subjek untuk menambah waktu berkualitas bersama keluarga.mengunjugi sanak saudara kadangjuga mengunjungi menjalin silaturahmi pada teman-teman lama subjek.

Aspek afek positif, semua subjek menunjukkan gambaran afek positif seperti bahagia dengan kehidupannya saat ini, merasa gembira untuk menjalani aktivitas-aktivitas sehari-hari, merasa senang jika dapat membantu sesama terutama bisa berperan aktif pada lingkungan sekitar.Merasa bangga atas pencapaian yang saat ini dicapai seperti memiliki anggota dalam keadaan sempurna tanpa kekurangan apapun.Memiliki rasa kasih sayang dalam mengasuh anakanak maupun menjalankan peran sebagai seorang istri.Merasa puas dengan adanya waktu luang yang bisa dimanfaatkan bersama keluarga.

Afek negatif, pada subjek ketiga subjek menunjukkan adanya afek negatif pada kehidupan dimasa lalu. Subjek merasa dulu kehidupannya berat karena harus bekerja keras selain itu harus berperan sebagai ibu yang harus mengasuh anak-anak.Pada subjek II memiliki masa lalu yang 
cukup berat seperti pernah keguguran dan sempat menjadi korban pelecehan seksual.Namun pada saat ini afek tersebut tidak muncul, lebih di tonjolkan pada afek positif.

Adanya gambaran kebahagiaan subjektif pada subjek tidak terlepas dari fokus tujuan hidup subjek. Subjek berfokus pada keluarga agar bisa berkumpul dengan anggota keluarga dan anakanak tumbuh menjadi anak-anak yang patuh merupakan kebahagiaan terhadap subjek. Hal ini sejalan dengan penelitian Patnani (2012) mengeumakakn bahwa kebahagiaan yang paling utama bagi perempuan dilihat dari segi usia, pekerjaan dan penikahan adalah keluarga. komponen bahagia akan secara konsisten mendukung kebahagiaan perempuan adalah kognisi yang positif dan pengendalian.

Inti dari ini semua adalah letak kebahagiaan bukanlah dengan memiliki istana yang megah, mobil yang mewah, harta yang melimpah. Letak kebahagiaan adalah di dalam hati. Nabi shallallahu 'alaihi wa sallam bersabda:

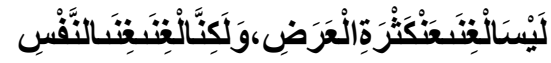

Yang artinya: "Yang namanya kaya (ghina') bukanlah dengan banyaknya harta (atau banyaknya kemewahan dunia). Tetapi yang namanya ghina' adalah hati yang selalu merasa cukup.” (HR. Bukhari dan Muslim)(Tuasikal, 2009).

\section{KESIMPULAN DAN SARAN}

Ketiga subjek memunculkan gambaran kebahagiaan subjektif hal ini terbukti dengan kepuasan pada pencapaian dirinya sendiri. Subjek tidak merasa bahwa tidak ada penyesalan atau menyalahkan diri sendiri telah melakukan pekerjaan putting out system. Subjek merasa gembira karena selain bisa menghasilkan tetapi bisa berkumpul dengan keluarga. Subjek merasa bersyukur bisa sepenuhnya mengasuh anak-anak dengan baik. Subjek merasa bahwa saat ini saatnya untuk mengasuh anak sendiri tanpa ada bantuan dari pengasuh. Subjek merasa puas dan bahagia dengan kehidu pan keluarga, terbukti dengan adanya pola komunikasi yang baik antara anak dan suami. Keluarga subjek mendukung subjek untuk bekerja dirumah. Meskipun subjek bekerja dirumah, tidak menghalangi subjek untuk bersosialisasi dengan tetangga sekitar. Hal ini terbukti dengan 
adanya pola komunikasi yang baik. Bahkan subjek juga turut aktif dengan kegiatan-kegaiatan yang dilakukan oleh lingkungan sekitar. Subjek merasa meski pada usia saat ini kesehatan mulai menurun, tetapi subjek bersyukur masih diberikan nikmat kesehatan hal ini menjadikan subjek merasa puas dengan keadaan kesehatan saat ini meskipun hasil yang diapatkan saat ini tidak sebesar penghasilan yang diapatkan dulu, subjek tetap menjalani puas dengan pekerjaan saat ini. Subjek mengatur keuangannya sedemikian rupa agar cukup.

Subjek merasa puas tetap produktif pada usia saat ini. Dan akan ada tambahan usaha yang dilakukan oleh ketiga subjek untuk menambah pemasukan, namun belum terfikirkan waktunya untuk menjalani usaha. Dengan bekerja putting out system subjek memiliki banyak watu luang yang bisa dimanfaatkan untuk keluarganya. Ketiga subjek memunculkan gambaran afek positif terkait dengan pekerjaan saat ini. Subjek merasa pekerjaan saat ini merupakan kemauan diri sendiri, bisa menyalurkan keahlian dengan baik, dan subjek tidak merasa terbebani dengan pekerjaan ini. Ketiga subjek tidak memunculkan gambaran afek negatif seperti adanya tanda tanda depresi, kesedihan, iri dan cemburu akan hasil yang didapatkan, marah, stress, perasaan penyesalan dan malu dan kecemasan.

\section{DAFTAR PUSTAKA}

Al-Quran dan Terjemahannya Departemen Agama RI. (2014). Jakarta: Wali.

Arif, I. S. (2016). Psikologi Positif: Pendekatan Saintifik Menuju Kebahagiaan. Jakarta: PT Gramedia Pustaka Utama.

Carr, A. (2004). Positive Psychology: The Science Of Happiness and Human Strengths. New York: Brunner Routledge.

Creswell, J. W. (2010). Research Design Pendekatan Kualitatif, Kuantitatif dan Mixed. Yogyakarta: Pustaka Belajar.

Diener, E., Ryan, K. (2009). Subjective Well Being: a General Overview. Journal Psychology, 39, 391-406. Retrieved from https://doi.org/10.1177/008124630903900402

Diener, E. (2009). The Science of Well-Being. New York: MA: Springer.

Eid, M., Larsen, R. J. (2008). The Science of Subjective Well-Being. New York: The Guilford Press.

Fajerman. (2013). Review of the Regulatory Framework for Homeworkers in Indonesia. Jakarta: International Labour Organization.

Fauziah, L., Mashudi., Mariyati, L. I., Choiriyah, I. U. (2017). Wage System of Female Worker Based on Putting Out System in Sidoarjo Regency. MIMBAR, 33, 149-157.

Hurlock, E. B. (1980). Psikologi Perkembangan: Suatu Pendekatan Sepanjang Rentang Kehidupan Edisi Kelima. Jakarta: Erlangga.

Kartono, K. (2007). Psikologi Wanita Jilid I (Mengenal Gadis Remaja dan Wanita Dewasa). 
Bandung: Mandar Maju.

Kasturi, T. (2015). Kebahagiaan Selayang Pandang: Perspektif Psikologi dan Islam Serta Titik Temu dari Keduanya. In Prosiding Seminar dan Sarasehan Enhancing Human Happines Edisi Revisi (pp. 19-28). Sidoarjo: Fakultas Psikologi Universitas Muhammadiyah Sidoarjo.

Moleong, L. J. (2017). Metode Penelitian Kualitatif(Edisi Revi). Bandung: PT Remaja Rosdakarya. Myers, D. G. (2012). Psikologi Sosial. Jakarta: Salemba Humanika.

Nilakusmawati, D. P. E., Susilawati, M. (2012). Studi Faktor-Faktor yang Mempengaruhi Bekerja di Kota Denpasar. Jurnal Kependudukan Dan Pengembangan Sumber Daya Manusia, 8, 2631. Retrieved from https://ojs.unud.ac.id/index.php/piramida/aricle/view

Patnani, M. (2012). Kebahagiaan Pada Perempuan. Jurnal Psikogenesis, 1, 56-64. Retrieved from https://academicjournal.yarsi.ac.id/index.php/Jurnal-Online-Psikogenesis/Article/download/36

Prasetyo, A. R. (2015). Gambaran Career Happiness Plan Pada Dosen. Jurnal Psikologi, 14, 174 182. Retrieved from https://ejournal.undip.ac.id/index.php/psikologi/article/download/

Roboth, J. Y. (2015). Analisis Work Family Conflic, Stress Kerja dan Kinerja Wanita Berperan Ganda Pada Yayasan Compassion East Indonesia. Jurnal Riset Bisnis Dan Manajemen, 3, 3346. Retrieved from https://ejournal.unsrat.ac.id/index.php/jbrm/article/view/7517

Santrock, J. W. (2011). Life-Span Development: Perkembangan Masa-Hidup (Ketiga Bel). Jakarta.

Schimmel, J. (2009). Development as Happiness: The Subjective Perception of Happiness and UNDP's Analysis of Poverty, Wealth and Development. Journal of Happiness Studies. Retrieved from https://www.researchgate.net/publication/24008708_Development_as_Happiness_The_Subject ive_Perception_of_Happiness_and_UNDP's_Analysis_of_Poverty_Wealth_and_Development Sugiyono. (2014). Metode Penelitian Küantitatif $\bar{R} \& D$. Bandung: Alfabeta.

Tuasikal, M. A. (2009). Letak Kebahagiaan adalah Di Hati. Retrieved from https://rumaysho.com/\%0A335-letakkebahagiaan-adalah-di-hati.html

Wijaya, H. R. (1995). Perlindungan Sosial Pada Perempuan Pekerja Rumahan: Riset Aksi Pemberdayaan Perempuan Untuk Mengubah Kondisi Kerjanya. In T. O. Ihromi (Ed.), Kajian Wanita dalam Pembangunan (pp. 401-429). Jakarta: Yayasan Obor Indonesia. 